\title{
Correction to: State-Space Models for Assisting Loosely Coupled Inductive Power Transfer Systems Analysis
}

\author{
Emilio Tanowe Maddalena ${ }^{1} \cdot$ Ruben Barros Godoy ${ }^{2}$
}

Published online: 16 December 2017

(c) Brazilian Society for Automatics-SBA 2017

\section{Correction to: \\ Journal of Control, Automation and Electrical Systems https://doi.org/10.1007/s40313-017-0354-7}

In the original published article, Emilio Tanowe Maddalena's last name was spelled incorrectly. It is correct as reflected here. The original article has also been updated.

1 Divisão de Engenharia Eletrônica, Insituto Tecnológico de Aeronáutica, São José dos Campos, SP 12228-900, Brazil

2 Faculdade de Engenharias, Arquitetura e Geografia, Universidade Federal de Mato Grosso do Sul, Campo Grande, MS 79070-900, Brazil 